\title{
UJI KUALITAS TANAH LEMPUNG DAN BATU BATA MERAH GAREGEH BUKITTINGGI
}

\author{
Aidhia Rahmi ${ }^{1}$ dan Azhari Syarief ${ }^{2}$ \\ ${ }^{1}$ Pendidikan Fisika, STKIP PGRI Sumatera Barat \\ ${ }^{2}$ Pendidikan Geografi, STKIP PGRI Sumatera Barat \\ Email: aidhiarahmi@yahoo.co.id \\ http://dx.doi.org/10.22202/jrfes.2014.v1i1.1183
}

\begin{abstract}
Garegeh area Bukittinggi is one of the central production of bricks in Sumatra Barat.Batu bricks made with clay main ingredient. This study aims to analyze the mineral content and determine the crystal structure of the clay material used as brick-making. Assessment of the quality of the brick production was also undertaken to determine whether the quality meets the standards or not. Test the quality of bricks include: water absorption test, the size, dimensions of color, absorption of water and salt content. The test results are then compared to the quality of Indonesian National Standard (SNI) brick. From the results of XRD characterization showed Garegeh area contains clay minerals Al2H2K0.7O12Si4 (illite), Al2Si2O5 (OH) 4 (Kaolit), illite-smectite and $\mathrm{SiO} 2$ (Silicon Oxide). Shaped monoclinic crystal structure, anorthic and hexagonal. Brick-quality test conducted by taking 10 random samples from bricks freshly prepared dibakar.Dari uptake assay results obtained persentanse high uptake is $\pm 80 \%$.Penyerapan high visible brick less dense and there are many cavities. as well as the surface of the bricks were cracked and uneven. Size bricks meet the module M6 with an average length, width and height respectively $22.2 \mathrm{~cm}, 11.3 \mathrm{~cm}$ and $6.4 \mathrm{~cm}$.
\end{abstract}

Keywords: XRD, monoclinic, and hexagonal anorthic

\begin{abstract}
Abstrak
Daerah Garegeh Bukittinggi merupakan salah satu sentral produksi batu bata di Sumatera Barat.Batu bata dibuat dengan bahan utama tanah lempung. Penelitian ini bertujuan untuk menganalisa kandungan mineral dan mengetahui struktur kristal dari tanah lempung yang digunakan sebagai bahan pembuatan batu bata. Kajian terhadap kualitas batu bata hasil produksi juga dilakukan untuk mengetahui apakah kualitas memenuhi standar atau tidak. Uji kualitas batu bata meliputi: uji serapan air, ukuran, dimensi warna, serapan air dan kandungan garam. Hasil pengujian ini kemudian dibandingkan dengan mutu Standar Nasional Indonesia (SNI) batu bata. Dari hasil karakterisasi XRD menunjukkan tanah lempung daerah Garegeh mengandung mineral $\mathrm{Al}_{2} \mathrm{H}_{2} \mathrm{~K}_{0.7} \mathrm{O}_{12} \mathrm{Si}_{4}$ (Illite), $\mathrm{Al}_{2} \mathrm{Si}_{2} \mathrm{O}_{5}(\mathrm{OH})_{4}$ (Kaolit), Illite-smectite dan $\mathrm{SiO}_{2}$ (Silicon Oxide). Dengan struktur kristal berbentuk monoclinic, anorthic dan hexagonal. Uji kulitas batu bata dilakukan dengan mengambil 10 sampel secara acak dari batu bata yang baru siap dibakar.Dari hasil uji serapan diperoleh persentanse serapan yang tinggi yaitu $\pm 80 \%$.Penyerapan yang tinggi terlihat dari batu bata yang kurang padat dan banyak terdapat rongga-rongga.Serta permukaan batu bata yang retak dan tidak rata. Ukuran batu bata memenuhi modul M-6 dengan rata-rata panjang, lebar dan tinggi masing-masingnya $22,2 \mathrm{~cm}, 11,3$ $\mathrm{cm}$ dan $6,4 \mathrm{~cm}$.
\end{abstract}

Kata kunci: XRD, monoclinic, anorthic dan hexagonal 


\section{PENDAHULUAN}

Penggunaan batu bata dalam dunia kon-truksi baik sebagai pembentuk elemen struktur maupun non struktur belum dapat tergantikan.Hal ini dapat dilihat dari masih banyaknya proyek konstruksi yang memanfaatkan batu bata sebagai dinding pada pembangunan gedung dan perumahan, pagar, saluran, dan pondasi.Daerah Indonesia yang sering dilanda bencana gempa bumi, baik gempa vulkanik maupun tektonik.Bencana ini mengakibatkan korban jiwa, bangunan yang retak-retak bahkan ada yang sampai runtuh.

Seiring dengan perkembangan teknologi dalam perencanaan bangunan tahan gempa, telah dikembangkan suatu pendekatan desain alternatif untuk mengurangi resiko kerusakan bangunan akibat gempa dan mampu mempertahankan integritas komponen struktural dan non-struktural terhadap gempa kuat [1].Upaya non-struktural yang dapat dilakukan untuk mengantisipasi agar tidak terjadinya kerusakan bangunan adalah memilih bahan bangunan yang berkualitas bagus dan tahan gempa [2].Batu bata yang merupakan salah satu komponen bahan bangunan yang berhubungan dengan kekuatan sebuah bangunan permanen [3].Upaya peningkatan kualitas batu bata telah banyak dilakukan diantaranya mengkaji pengaruh jenis bahan bakar serta campuran pasir terhadap kuat tekan bata dan optimasi suhu pembakaran [4].

Kelurahan Garegeh merupakan salah satu lokasi sentral pengrajin batu bata di Sumatera Barat. Namun sampai saat ini belum pernah dilakukan kajian untuk mengetahui kandungan mineral dan struktur kristal tanah lempung dari daerah tersebut. Masih kurangnya berbagai macam referensi mengenai kualitas batu bata yang layak dipakai, serta untuk mengetahui apakah batu bata yang diproduksi telah memenuhi standar SNI (Badan Standarisasi Nasional, 2002), maka penelitian ini penting dilakukan dan dapat memberikan informasi kepada masyarakat dapat lebih selektif membeli batu bata yang berkualitas.

\section{METODOLOGI PENELITIAN}

Penelitian ini dilakukan melalui pengamatan secara langsung dan uji labolatorium terhadap batu bata hasil produksi dan tanah lempung yang digunakan sebagai bahan pembuatan batu bata. Uji kualitas batu bata dibatasi pada uji ukuran dan dimensi, uji kadar garam, uji penyerapan, uji dering, uji warna. Sedangkan terhadap tanah lempung dilakukan karakterisasi dengan menggunakan X-Ray Difraction (XRD) menggunakan menggunakan mesin XRD tipe e'pert pro PW304/60 dari PANlytical. Sumber sinar-X dari sinar $\mathrm{CuK}_{\alpha}$ pada panjang gelombang $(\lambda)$ $=0.1548 \mathrm{~nm}$ di laboratorium Fisika Universitas Negeri Padang.

\subsection{Uji Ukuran dan Dimensi}

Sampel batu bata yang akan diukur panjang, lebar dan tinggi diambil 10 buah secara acak. Hasil pengukuran ini kemudian dibandingkan dengan ukuran standard SII-0021-78. Standard SII-0021-78 diperlihatkan pada Tabel 1. Tingkat penyimpangan ukuran batu bata standard menurut SK SNI S 041989 F diperlihatkan pada Tabel 2

Tabel 1 Modul standar ukuran batu bata menurut SII-0021-78

\begin{tabular}{lccc}
\hline Modul & $\begin{array}{c}\text { Panjang } \\
(\mathrm{mm})\end{array}$ & $\begin{array}{c}\text { Lebar } \\
(\mathrm{mm})\end{array}$ & $\begin{array}{c}\text { Tebal } \\
(\mathrm{mm})\end{array}$ \\
\hline M-5a & 190 & 90 & 65 \\
M-5b & 190 & 140 & 65 \\
M-6 & 220 & 110 & 55 \\
\hline
\end{tabular}

Tabel 2 Tingkat penyimpangan ukuran batu bata merah menurut SK SNI S $041989 \mathrm{~F}$

\begin{tabular}{|c|c|c|c|c|c|c|}
\hline \multirow[t]{2}{*}{ Kelas } & \multicolumn{3}{|c|}{$\begin{array}{l}\text { Modul M-5a dan M- } \\
5 \mathrm{~b}\end{array}$} & \multicolumn{3}{|c|}{ Modul M-6 } \\
\hline & $\mathrm{P}$ & $\mathrm{L}$ & $\mathrm{T}$ & $\mathrm{P}$ & L & $\mathrm{T}$ \\
\hline 25 & 2 & 3 & 5 & 2 & 3 & 5 \\
\hline 50 & 2 & 3 & 4 & 2 & 3 & 5 \\
\hline 100 & 2 & 3 & 4 & 2 & 3 & 4 \\
\hline
\end{tabular}

2.2 Uji Kadar Garam (Abdullah, 2004)

Batu bata diletakan berdiri dalam ember.Sebagian batu bata terendam dalam air dan sebagian lagi tidak.Perendaman dilakukan 
selama seminggu. Pada proses ini air akan terserap ke dalam bata lewat bagian yang terendam di dalam air, kemudian mengalir ke atasnya dan menguap melalui permukaan bata yang berhubungan dengan udara. Dalam perjalanan air di batu bata dari bawah ke atas disertai pula dengan membawa garam yang telah terlarut. Apabila permukaan bata mengandung garam akan tampak bercakbercak putih.

\subsection{Uji Penyerapan}

Uji penyerapan batu bata ini diawali dengan menimbang batu bata kering $\left(\mathrm{M}_{\mathrm{d}}\right)$.Kemudian direndam dalam air selama 1 menit.Setelah direndam selama 1 menit, kemudian ditimbang lagi $\left(\mathrm{M}_{\mathrm{s}}\right)$. Daya penyerapan dihitung dengan rumus:

$$
\text { Daya penyerapan }=\frac{M_{S}-M_{d}}{L x \text { menit }}
$$

Dimana: $\mathrm{L}=$ luas permukaan batu bata

\subsection{Uji Dering}

Pengujian bunyi dilakukan dengan memegang dua batu bata dan kemudian memukulnya satu sama lain, dengan pukulan tidak terlalu keras pada kedua bata tersebut. Bata yang baik akan mengeluarkan bunyi dering.

\subsection{Uji Warna}

Karakterisasi ini dilakukan dengan melihat langsung warna batu bata yang telah dicetak sebelum dan sesudah dibakar.

\subsection{Karakterisasi XRD}

Tanah lempung yang diperoleh dalam bentuk butiran yang kasar, untuk menghasilkan partikel berukuran kecil dilakukan top-down (pengecilan ukuran) yaitu memecah partikel berukuran besar menjadi partikel berukuran mikrometer (Enzo salami, 2010) melalui proses benefisiasi [4] setelah selesai baru dilakukan karakterisasi dengan Mesin XRD tipe e'pert pro PW304/60 dari PANlytical.

\subsection{Uji ukuran dan dimensi}

Setelah dilakukan pengukuran panjang, lebar, dan tebal dari 10 sampel batu bata yang diambil secara acak. Ukuran, keadaan permukaan dan dimensi dapat dilihat dari Tabel 3

Tabel 3 Ukuran, dimensi dan kesikuan batu bata daerah Garegeh

\begin{tabular}{lllllc}
\hline No & $\begin{array}{l}\text { P } \\
(\mathrm{cm})\end{array}$ & $\begin{array}{l}\mathrm{L} \\
(\mathrm{cm})\end{array}$ & $\begin{array}{l}\mathrm{T} \\
(\mathrm{cm} \\
\end{array}$ & $\begin{array}{l}\text { Permuka } \\
\text { An }\end{array}$ & $\begin{array}{l}\text { Kes } \\
\text { iku } \\
\text { an }\end{array}$ \\
\hline 1 & 22,5 & 11,3 & 6,0 & $\mathrm{R}$ dan TR & $\mathrm{B}$ \\
2 & 22,3 & 11,2 & 6,2 & $\mathrm{R}$ dan TR & $\mathrm{KB}$ \\
3 & 22,8 & 11,3 & 6.5 & $\mathrm{R}$ dan TR & $\mathrm{B}$ \\
4 & 22,1 & 11,5 & 6,4 & $\mathrm{R}$ dan TR & $\mathrm{B}$ \\
5 & 22,6 & 11,0 & 6,3 & $\mathrm{R}$ dan TR & $\mathrm{B}$ \\
6 & 22,3 & 11,1 & 6,4 & $\mathrm{R}$ dan TR & $\mathrm{KB}$ \\
7 & 22,4 & 11,4 & 6,1 & $\mathrm{R}$ dan TR & \\
8 & 22,4 & 11,3 & 6,2 & $\mathrm{R}$ dan TR & $\mathrm{B}$ \\
9 & 22,3 & 11,6 & 6,2 & $\mathrm{R}$ dan TR & $\mathrm{KB}$ \\
10 & 22,5 & 11,2 & 6,4 & $\mathrm{R}$ dan TR & $\mathrm{B}$ \\
\hline
\end{tabular}

Ket $: \mathrm{R}=$ Retak, $\mathrm{TR}=$ Tidak rata $\mathrm{B}=$ Baik dan KB kurang Baik

Hasil pengukuran ini kemudian dibandingkan dengan modul batu bata SII0021-78 (Tabel 2.3). Setelah diukur rata rata panjang, lebar dan tebal batu bata diperoleh ukuran batu bata mendekati modul 6.

Sedangkan untuk dimensi batu bata meliputi keadaan permukaan, kesikuan, dan ketajaman.Berdasarkan hasil pengamatan di lapangan, secara umum dapat disimpulkan dimensi batu bata kurang tajam. Pada saat ini pengrajin batu bata Garegeh mengalami kesulitan mendapat kualitas tanah lempeng yang berkualitas baik. Karena pengerukan tanah lempung dilakukan terus menerus dan sulit untuk mendapatkan sumber tanah lempung yang berkualitas baik. Ini mengakibatkan batu bata setelah dibakar pinggir-pinggirnya mudah pecahnya dan adanya rongga-rongga pada permukaan batu bata.

\section{HASIL DAN PEMBAHASAN}




\subsection{Uji Serapan}

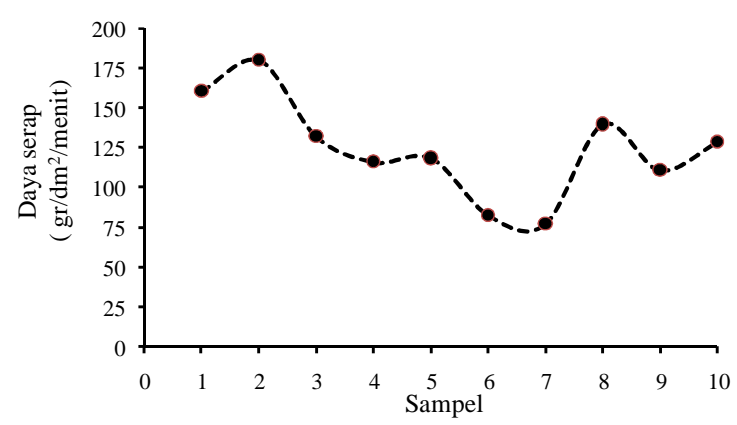

Gambar 1 Perbandingan daya serap air antara kedua batu bata

Dari gambar 1 daya serapan air batu bata.Koefisien penyerapan ini melebihi standard penyerapan batu bata yaitu 20 $\mathrm{gr} / \mathrm{dm}^{2} /$ menit[5]. Tingginya koefisien ini lebih dipengaruhi oleh kualitas tanah lempung yang digunakan.

\subsection{Uji Kadar Garam}

Uji kadar garam menunjukkan bahwa batu bata daerah ini tidak mengandung kadargaram. Ini terlihat dari hasil pengamatan bahwa setelah batu bata direndam sampai dua minggu tidak terlihat adanya bercak-bercak putih.Ini didukung juga dengan hasil karakterisasi XRD menunjukkan bahwa unsur yodium tidak terkandung dalam tanah lempung.

\subsection{Karakterisasi stuktur kristal}

Karakterisasi struktur kristal menggunakan sumber sinar $\mathrm{X}$, dari pancaran $\mathrm{CuK}_{\alpha}$ pada panjang gelombang $(\lambda)=0.1548 \mathrm{~nm}$. Analisis XRD pada penelitian ini digunakan untuk mengetahui komposisi jenis mineral dan struktur kristal yang ada pada sampel tanah lempung. Hasil uji difraktometer diperlihatkan pada Gambar 2.

Komposisi mineral lempung daerah Garegeh $\quad \mathrm{Al}_{2} \mathrm{H}_{2} \mathrm{~K}_{0.7} \mathrm{O}_{12} \mathrm{Si}_{4} \quad$ (Illite), $\mathrm{Al}_{2} \mathrm{Si}_{2} \mathrm{O}_{5}(\mathrm{OH})_{4}$ (Kaolit), Illite-smectite dan $\mathrm{SiO} 2$ (Silicon Oxide). Struktur kristal dari monoclinic, anorthic dan hexagonal Tabel 3.3 menunjukkan hasil konstanta kisi dari tanah lempung.

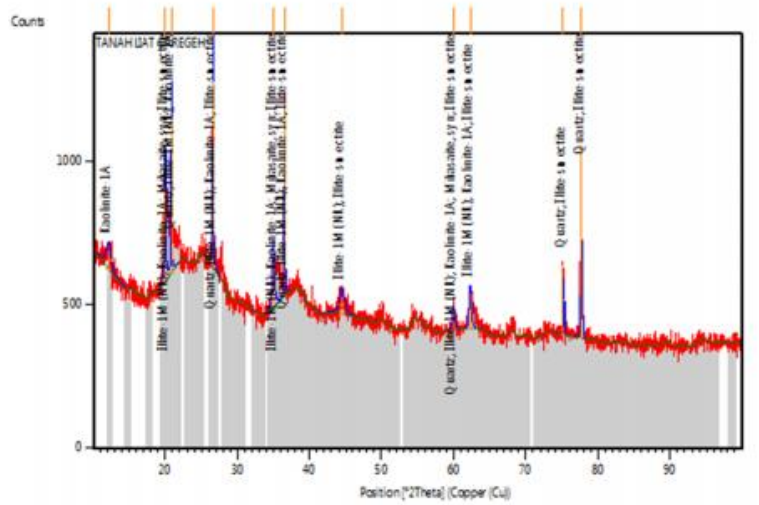

Gambar 2 Difraktokram sampel tanah lempung lambah

Tabel 3 Konstanta kisi

\begin{tabular}{|c|c|c|c|}
\hline Mineral & Hkl & $2 \theta$ & $\begin{array}{c}\text { Konstanta } \\
\text { kisi }\end{array}$ \\
\hline \multirow{4}{*}{ Illite } & [110] & 20,02 & 4,43 \\
\hline & {$[-131]$} & 35,02 & 2,56 \\
\hline & [112] & 29,16 & 3,06 \\
\hline & {$[-112]$} & 24,29 & 3,66 \\
\hline \multirow{4}{*}{ Kaolinite } & [002] & 24,84 & 3,58 \\
\hline & [001] & 12,34 & 7,16 \\
\hline & {$[-202]$} & 38,39 & 2,34 \\
\hline & [131] & 39,22 & 2,29 \\
\hline \multirow{4}{*}{$\begin{array}{l}\text { Illite- } \\
\text { Smectite }\end{array}$} & {$[-112]$} & 24,39 & 3,64 \\
\hline & [001] & 8,83 & 10,01 \\
\hline & [020] & 19,74 & 4,49 \\
\hline & {$[-131]$} & 34,96 & 2,56 \\
\hline
\end{tabular}

\section{KESIMPULAN}

Dari hasil penelitian ini menunjukkan bahwa secara keseluruhan kualitas batu bata Garegeh lebih baik, tapi perlunya upaya peningkatan kualitas batu bata kedepannya.Juga kepada masyarakat dapat lebih hati-hati dalam membeli.

\section{UCAPAN TERIMA KASIH}

Terimakasih kepada unit UP3M Sekolah Tinggi Keguruan dan Ilmu Pendidikan (STKIP) PGRI Sumbar ynag telah membiayai penelitian ini.

\section{DAFTAR PUSTAKA}

[1] Halauddin, M. Ginting, Irfan Gustian, dan Suhendra. 2011. Pengaruh Penambahan Polimer Emulsi Vinyl Acetate co Acrylic 
Pada Tanah Lempung Dengan Objek Pengujian Pada Kekuatan Batu Bata Menggunakan Metode Uniaxial. 7 (1): 622-627.

[2] Bandan Standarisasi Nasional P.U, 1991, SK SNI S-04-1991, Tentang Bata Merah Pejal, Yayasan Badan Penerbit Pekerjaan Umum, Jakarta

[3] Tanarwanto M., dan Susanto T., 2003, Proyek Akhir :Uji Batu Bata Merah, Jurusan Teknik Sipil STTR Cepu, Blora.

Enzo salami, Umberto tessari, Nicolo Colombia, Micol Mstrocico. 2010. Improved Gravitational Grain Size Separation Method. Applied Clay science.Volume 48(4): 612-614.

[4] Abdulloh. 2004. Evaluasi Teknik Uji Geser dan Uji Tekan dalam Kajian Pengaruh
Kadar Air dan Penambahan Zat Limbun terhadap karakteristik Plastisitas lempung asal Dsn. Pandisari Ds. Sawoo Kec. Kutorejo Kab. Mojokerto, Bandung: Departemen Kimia Fakultas MIPA

[5] Guntur R, Sulistia, Subandi.. Penelitian Kualitas Bata Dan Pengaruh Jenis Bahan Bakar Serta Campuran Pasir Terhadap Kuat Tekan Bata. Majalah Ilmiah STTR Cepu: ISSN 1693 - 7066

[6] Mardiyati dan Harjana, 2010, Optimasi suhu pembakaran batu bata merah dengan penambahan limbah batu bata untukmeningatkan kualitas batu bata. Prosiding pertemuan ilmiah XXIV. April 2010. 317-322 